\title{
Minat Baca Siswa dalam Pembelajaran PPKn (Studi pada Kelas VII di SMP N 4 Kota Solok)
}

\author{
Aci Zakia Yulia, Hasrul, Al Rafni \\ Program Studi Pendidikan Pancasila dan Kewarganegaraan \\ Universitas Negeri Padang \\ E-mail: acizakia26@gmail.com
}

\begin{abstract}
ABSTRAK
Penelitian ini bertujuan untuk melihat minat baca siswa kelas VII dalam pembelajaran PPKn serta mengetahui upaya yang dilakukan untuk meningkatkan minat baca. Dalam hal ini minat baca merupakan salah satu aspek yang dapat mempengaruhi pemahaman siswa terhadap materi pembelajaran sehingga dapat menunjang hasil belajar siswa. Penelitian ini merupakan penelitian kuanrtitatif dengan metode deskriptif yang menggambarkan bagaimana minat baca siswa kelas VII dalam pembelajaran PPKn. Sampel dipilih dengan menggunakan rumus Solvin yakni sebanyak 60 siswa kelas VII. Tekhnik ini digunakan agar pengambilan sampel atau elemen secara acak dimana setiap elemen atau anggota populasi memiliki kesempatan yang sama untuk terpilih menjadi sampel. Hasil penelitian menunjukkan bahwasanya minat baca siswa kelas VII di SMP N 4 Kota Solok pada kategori cukup dengan persentase 65,1\%. Upaya guru dalam meningkatkan minat baca terlihat dengan memberikan motivasi serta pemberian tugas yaang dapat menunjang minat baca siswa dalam pembelajaran PPKn
\end{abstract}

Kata Kunci : Minat Baca Siswa, Pembelajaran PPKn

\section{ABSTRACT}

The study aims to look at the interest of class VII students in learning about PPKn and to know the efforts made to increase read interest. In this case, reading interest is one aspect that can affect students ' understanding of learning materials so that they can support student learning outcomes. This research is a quanrtitular study with a descriptive method that describes how the interest of class VII students read in the study of PPKn. Samples were chosen using Solvin's formula of 60 grade VII students. The technique is used to randomly capture samples or elements where each element or member of a population has the same opportunity to be selected into a sample. The results of the study showed that the interest of reading students in grade VII in SMP N 4 Kota Solok in categories is enough with a percentage of $65.1 \%$. Teachers ' efforts to increase reading interest are seen by providing motivation as well as giving the task of Yaang to support students ' interest in learning about PPKn.

Keywords: Interest reading students, learning about PPKn

PENDAHULUAN

Salah satu aspek yang mempengaruhi pemahaman dan hasil belajar siswa adalah minat baca yang dimiliki oleh siswa khususnya dalam pembelajaran PPKn. Namun kenyataannya minat baca masyarakat khususnya siswa masih rendah. Hal ini terbukti berdasarkan hasil survei pada Tahun 2011 oleh United Nations 
Education, Scientific and Cultural Organization (UNESCO) randahnya minat baca dibuktikan dengan indeks membaca masyarakat Indonesia hanya 0,001 , artinya dari seribu penduduk Indonesia, hanya ada satu orang yang memiliki minat baca tinggi (Triatma, 2016 : 167). Sedangkan menurut data UNDP tahun 2016, angka melek huruf Indonesia termasuk yang baik bila dibandingkan dengan banyak negara berkembang lainnya.

Berdasarkan observasi yang penulis lakukan pada 16 Januari 2019 penulis melihat bahwa hasil belajar siswa dalam pembelajaran PPKn masih belum mencapai target yang diinginkan. Hal ini menjadi salah satu indikasi bagaimana pemahaman siswa terhadap materi, yang salah satunya dipengaruhi oleh minat baca siswa dalam pembelajaran. Selain itu, dalam pengamatan penulis saat proses pembelajaran dikelas VII. B ketika siswa ditugaskan untuk membaca terlihat bahwa belum semua siswa melakukan kegiatan membaca, sehingga jika diberi pertanyaan terkait bacaan siswa tidak mampu menjawab pertanyaan tersebut dengan baik. Tinggi rendahnya minat baca juga dapat dipengaruhi oleh kebijakan sekolah, dan perpustakaan sebagai salah satu wadah dalam peningkatan minat baca pada siswa.

Rahardini (2003 ; 506)

menyebutkan bahwa peran guru dalam meningkatkan minat baca harus dimulai dari dirinya sendiri. Hal ini dapat dikatakan bahwa seorang guru harus mewujudkan pribadi yang efektif untuk dapat melaksanakan fungsi dan tanggung jawabnya sebagai guru. Upaya guru dalam peningkatan minat baca siswa harus dimulai dari dirinya sendiri sehingga dapat $\begin{array}{lrr}\text { memotivasi } & \text { siswa } & \text { untuk } \\ \text { meningkatkan } & \text { minat } & \text { baca. }\end{array}$ Penggunaan metode pembelajaran yang bervariasi dan pemberian tugas yang dapat menunjang minat baca siswa juga harus menjadi perhatian penting bagi guru PPKn

\section{METODE PENELITIAN}

Metode penelitian yang digunakan dalam penelitian ini adalah deskriptif kuantitatif. Menurut Sugiyono (2016:8) metode penelitian kuantitatif dapat diartikan sebagai penelitian yang berlandaskan pada filsafat positivism, digunakan untuk meneliti pada populasi atau sampel tertentu. Pengumpulan data menggunakan angket yang diberikan kepada siswa sebagai instrument penelitian. Data ini diolah dengan menghitung Tingkat Capaian Responden (TCR) sehingga analisis data bersifat kuantitatif, dengan tujuan untuk menguji hipotesis yang telah ditetapkan. Menurut Arikunto (2010:3) penelitian deskriptif merupakan penelitian yang dimaksudkan untuk menyelidiki keadaan, kondisi atau halhal lain yang sudah disebutkan, yang hasil dipaparkan dalam bentuk laporannya penelitian. Adapun yang dideskripsikan dalam penelitian ini sesuai dengan hasil penelitian yaitu tentang minat baca siswa dalam pembelajaran PPKn.

\section{HASIL DAN PEMBAHASAN}

1. Minat Baca Siswa dalam Pembelajaran PPKn di SMP N 4 Kota Solok

Menurut Budimansyah \& Suryadi (2008 : 68) Pendidikan Pancasila dan Kewarganegaraan (PPKn) merupakan salah satu bidang kajian yang mengemban misi nasional untuk mencerdaskan kehidupan bangsa Indonesia. Dalam hal ini PPKn 
merupakan salah satu mata pelajaran wajib yang harus diberikan pada semua jenjang pendidikan karena bertujuan mengembangkan potensi individu agar menjadi warga negara Indonesia yang berakhlak mulia, cerdas, partisipatif, bertanggung jawab, memiliki rasa kebangsaan dan cinta tanah air. Selain itu, PPKn secara teoritik dirancang sebagai subjek pembelajaran yang memuat dimensidimensi kognitif, afektif dan psikomotorik yang saling terintegrasi dalam konteks subtansi ide, nilai, konsep, dan moral Pancasila, kewarganegaraan yang demokratis, dan bela negara. Oleh karena itu, minat baca siswa sangat penting dalam pembelajaran PPKn sehingga untuk melihat minat baca siswa dalam pembelajaran PPKn. Indikator yang penulis simpulkan berdasarkan pendapat Burs dan Lowe dalam Prasetyono (2008;59) dan Dalman $(2013 ; 144)$ yang dapat diuraikan sebagai berikut :

a. Kebutuhan terhadap bacaan

b. Tindakan untuk mencari bahan bacaan

c. Keinginan untuk selalu membaca

d. Tindak lanjut terhadap bacaan

e. Kepemilikan terhadap bahan bacaan

f. Frekuensi dan kuantitas bacaan

Berdasarkan hasil angket minat baca terlihat bahwa siswa kelas VII memiliki minat baca yang bervariasi dalam pembelajran PPKn. Minat baca siswa kelas VII dapat dikategorikan menjadi lima kategori yaitu : sangat tinggi, tinggi, cukup, rendah, sangat rendah. untuk mengetahui kategori tersebut digunakan angket minat baca siswa dalam pembelajran PPKn. angket minat baca diberikan kepada 60 orang siswa kelas VII. Berikut ini diagram yang menggambarkan minat baca siswa kelas VII berdasarkan indikator minat baca.

Gambar 1.1

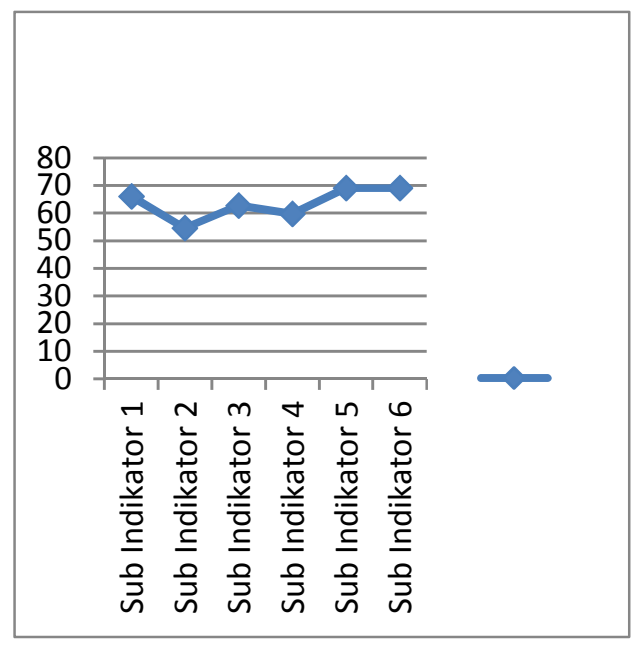

Berdasarkan diagram diatas diperoleh bahwa rata-rata tingkat capaian responden adalah 65,1 \% dengan kategori "cukup". Hal ini membuktikan bahwa minat baca siswa kelas VII dalam pembelajaran PPKn di SMP N 4 Kota Solok belum pada hasil yang sangat memuaskan. Harus ada beberapa evaluasi yang dilakukan oleh pihak sekolah maupun oleh guru yang bersangkutan sehingga kategori "cukup" bisa menjadi "tinggi". Minat baca siswa adalah salah satu aspek yang berpengaruh terhadap pemahaman siswa yang berbanding lurus dengan hasil belajar siswa dalam pemebelajaran PPKn. Oleh karena itu, jika dikaitkan dengan kurikulum 2013 dalam proses pembelajaran guru sebagai fasilitator harus mampu meningkatkan minat baca siswa. Guru dituntut lebih aktif dan kreatif dalam mengembangkan metode dan starategi pembelajaran yang dapat 
meningkatkan minat baca siswa dalam pembelajaran PPKn.

Jika dilihat dari hasil angket terlihat bahwa sub indikator paling rendah yaitu tindakan siswa terhadap bacaan dan tindak lanjut siswa dalam membaca. Hal ini memperkuat opini bahwa dalam pembelajaran PPKn, siswa belum dapat melakukan kegiatan membaca secara maksimal. Siswa melakukan kegiatan membaca menjelang ujian atau ketika disuruh guru saja. Ini artinya siswa belum memiliki kesadaran penuh akan pentingnya minat baca sehingga pemberian motivasi kepada siswa diharapkan dapat menumbuhkan minat baca siswa.

\section{Upaya Meningkatkan Minat Baca} Siswa dalam Pembelajaran PPKn

Upaya peningkatan minat baca dalam pembelajaran tidak bisa dipisahkan dengan peran guru dalam proses belajar mengajar itu sendiri. Sejalan dengan itu Tarigan \& Saifullah (2011:33) menyimpulkan bahwa upaya yang dilakukan guru dalam Kegiatan Belajar Mengajar (KBM) untuk meningkatkan minat baca adalah sebagai berikut :

a. Setelah melakukan apersepsi, guru umumnya menyuruh siswa baik secara perseorangan maupun berkelompok untuk membaca wacana yang terdapat dalam buku teks.

b. Kemudian, dilakukanlah tanya jawab atau diskusi terhadap isi wacana, baru setelah itu siswa diminta menjawab soal-soal latihan yang telah tersedia. Sebaliknya, banyak juga para guru yang langsung meminta para siswannya menjawab soal-soal latihan tersebut tanpa didahului oleh penjelasan, tanya jawab dan diskusi.

Pada pembelajaran PPKn di kelas VII SMP N 4 Kota Solok, upaya guru PPKn dalam meningkatkan minat baca siswa sudah baik. Hal ini tercermin dari upaya-upaya yang dilakukan guru PPKn diantaranya :

a. Guru menggunakan pazzle sebagai salah satu metode mengajar yang dapat meningkatkan minat baca siswa.

b. Guru memberikan motivasi siswa untuk meningkatkan minat baca, pemberian motivasi dilakukan dengan dua cara yaitu dengan bercerita kepada siswa tersebut tentang buku yang pernah dibaca.

c. Guru memberikan tugas kepada siswa sehingga dapat menunjang minat baca siswa dalam pembelajaran PPKn seperti mencari isu-isu terkini yang berhubungan dengan PPKn di koran.

d. Pentingnya minat baca khususnya dalam pembelajaran PPKn menjadikan guru mempunyai peran penting dalam upaya peningkatan minat baca tersebut. Minat baca yang baik diharapkan dapat meningkatkan pemahaman siswa dalam pembelajaran sesuai dengan tujuan yang akan dicapai.

\section{KESIMPULAN}

Berdasarkan hasil penelitian dan pembahasan yang telah dilakukan, secara umum minat baca siswa kelas VII dalam pembelajaran PPKn di SMP N 4 Kota Solok masih rendah. ini dapat dililihat dari kebutuhan siswa terhadap membaca, tindakan untuk mencari bacaan, rasa senang terhadap bacaan, ketertarikan terhadap bacaan, keinginan untuk selalu membaca, tindak lanjut dari a pa yang dibaca. dari indikator tersebut penulis dapat 
mengukur minat baca siswa sehingga penulis dapat menyimpulkan bahwa minat baca siswa kelas VII masih rendah.

$$
\text { Upaya guru dalam }
$$

meningkatkan minat baca siswa kelas VII di SMP N 4 Kota Solok sudah baik. Hal ini dapat dilihat dengan motivasi yang diberikan guru PPKn untuk membaca, selanjutnya guru PPKntelah menggunakan mengajar yang bervariasi walaupun ,serta memberikan tugas membaca kepada siswa. Namun belum dilakukan secara kontinu. Selanjutnya, SMP N 4 Kota Solok secara umum telah mendukung peningkatan minat baca siswa melalui kegiatan membaca lima belas menit sebelum jam pelajaran setiap selasa pagi, walaupun kegiatan tersebut masih belum menampakkan hasil yang signifikan. Perpustakaan sebagai salah satu sarana peningkatan minat baca siswa juga terlihat masih belum banyak kunjungan dari siswa setiap harinya, terutama siswa kelas VII ynag meminjam buku terkait dengan pembelajaran PPKn. dari data kualitatif yang penulis dapatkan bahwasanya siswa mengunjungi perpustakaan biasanya disuruh oleh guru. oleh karena itu dapat disimpulkan bahwasanya siswa melakukan kegiatan membaca karana tugas, disuruh guru, serta untuk pemenuhan nilai, bukan karena inisiatif sendiri.

\section{DAFTAR PUSTAKA}

Arikunto, Suharsimi. (2014). Prosedur Penelitian: Suatu Pendekatan Praktik. Jakarta: Rineka Cipta.

Tarigan, P. D., \& Saifulah, D. K. (2011). Membaca dalam Kehidupan. Bandung: Angkasa Bandung.

Budimansyah, \& Suryadi. (2008). PKN dan Masyarakat Multikulural. Bandung: UPI Program Studi Pendidikan Kewarganegaraan.

Rahardini, N. F. (2003). Peran Guru dalam Menumbuhkembangkan Minat Baca. Kajian Moral dan Kewarganegaraan , 506.

Somadayo, Samsu. (2011). Strategi dan Teknik Pembelajaran Membaca.

Sugiyono. (2016). Metode Penelitian Kuantitatif, Kualitatif, dan RED. Bandung: PT Alfabet. Yogyakarta: Graha Ilmu.

Triatma, I. N. (2016). Minat Baca pada Siswa Kelas Vi Sekolah Dasar Negeri. E-Jurnal Prodi Teknologi Pendidikan , 2. 